УдК 616-053.1:614.255 DOI 10.31640/3-4.2018(17) Надійшла 01.09.2017

\author{
О. В. ЛИСУНЕЦЬ, Н. В. ДІДИК
}

\title{
ДІАГНОСТИКА ВРОДЖЕНОЇ ПАТОЛОГІї У ПРАКТИЦ СІМЕЙНОГО ЛІКАРЯ
}

\author{
Кафедра пропедевтики дитячих захворювань і догляду за хворими дітьми \\ (зав. - проф. Л. М. Булат) Вінницького національного медичного університету \\ ім. М. І. Пирогова <olysunets@gmail.com>
}

\begin{abstract}
У статті наведено принципи класифікації вроджених вад розвитку. Описано клінічний випадок синдрому Прадера - Віллі у ранньому дитячому віці. Запропоновано алгоритм діагностичного пошуку, що сприяе верифікацї діагнозу сімейним лікарем. Виділено найважливіші клінічні детермінанти вродженої патологіі - стигми дизембріогенезу, порушення фізичного та психомоторного розвитку, гіпогонадизм, затяжна жовтяниия в період новонародженості, спещифічні патерни при інструментальних тестах.
\end{abstract}

Ключові слова: вроджена патологія, сімейний лікар, діагностика, діти, синдром Прадера - Віллі.

Вступ. В умовах реформування медичної галузі важливе місце посідає система охорони здоров'я дитячого населення. Патологія дитячого віку, iï діагностика, лікування, реабілітація та профілактика закладають підвалини суспільного здоров'я загалом та визначають якість життя, стратегію і перспективи розвитку держави [9]. Нині значну частку медичної допомоги надають сімейні лікарі, саме їхня компетентність, кваліфікованість, оволодіння мистецтвом аналізу та синтезу, імплементація міждисциплінарних зв'язків на практиці можуть забезпечити керованість демографічними детермінантами і показниками здоров'я населення [3, 5]. Оскільки первинний контакт пацієнта з лікарем вимагає від останнього ефективного рішення щодо встановлення діагнозу, обсягу медичної допомоги на первинному етапі, тактики лікарського супроводу і потреби спрямування на необхідний етап надання допомоги, актуальною є розробка простих алгоритмів послідовності дій сімейного лікаря для верифікацій нозології [4]. Разом з тим існує потреба у розширенні меж компетентності фахової спеціалазації лікарів загальної практики - сімейної медицини у максимально простий для сприйняття та засвоєння спосіб, оскільки щоденна рутинна робота сімейного лікаря знаходиться у континіумі міждисциплінарних та міжсекторальних взаємозв'язків медичної галузі. Тому аналіз, пошук, розробка міждисциплінарних алгоритмів діагностики патології дитячого віку залишаються актуальними, а лікарі мають можливість стати клініцистами [3-5].

Значну частку дитячих захворювань становить вроджена патологія. При цьому верифікація діагнозу, початок лікування не завжди своєчасні, а прогноз на виживання, збереження якості життя маленьких пацієнтів та їхніх родин залишається незадовільним. Тому ми вирішили ознайомити широке коло сімейних лікарів із засадами класифікації вроджених вад розвитку, виділити найбільш значущі клінічні детермінанти та параклінічні патерни, наявність яких у дітей вимагає заходів верифікації вродженої патології.

Мета дослідження - розробити алгоритм діагностики вродженої патології на етапі первинної медичної ланки на підставі вивчення клінічного випадку вродженого синдрому.

Матеріали і методи. Проаналізовано перебіг розвитку та історію хвороби дівчинки С., яка при народженні мала масу тіла 2100 г, довжину - 48 см, окружність голови - 32 см, окружність грудної клітки - 30 см; народилася в термін гестації 38 тиж від другої не обстежуваної вагітності (матір не перебувала на обліку, від першого шлюбу є соматично здоровий, старший на 1 рік і 2 міс хлопчик). Знаходилась у міській лікарні «Центр матері і дитини» Вінниці на етапах виходжування і лікування новонароджених дітей. Зі слів матері, вагітність перебігала без особливостей, тому вона не мала потреби у спостереженні. Дівчинка народилася з оцінкою за 
шкалою Апгар 7-8 балів. Період ранньої неонатальної адаптації асоціювався з патологічною втратою маси тіла, неонатальною жовтяницею, вираженою м'язовою гіпотонією, гіпорефлексією, порушенням харчової поведінки (в'яле смоктання з подальшою відмовою від грудного молока, зригування), схильністю до гіпотермії. Дитину переведено на змішане вигодовування. При лабораторно-інструментальному дослідженні гормональних та структурних порушень не виявлено. Параклінічні дослідження проводили за стандартними загальноприйнятими методиками у клінічній лабораторії міської лікарні. Нейросонографію виконували за діагностичною системою Philips HDI-4000 (США) за клінічними показаннями.

Разом з тим привертав увагу специфічний габітус немовляти: високий та вузький лоб, мигдалеподібні очі з тонкими, опущеними вниз повіками, великий і широкий ніс з тонкими крилами, тонка верхня губа, маленькі кисті і стопи, світла шкіра. На підставі анамнезу та даних клініко-параклінічних досліджень було діагностовано гіпоксично-ішемічну енцефалопатію у дитини з низькою масою тіла при народженні, малою до терміну гестації. Лікування і виходжування проводили відповідно до наказу № 584 від 29.08.2006 р «Протокол медичного догляду за новонародженою дитиною з малою масою тіла при народженні». Також було рекомендовано медико-генетичне консультування з метою виключення вродженої патології. Впродовж перших 8 міс життя дівчинку тричі госпіталізовували до міської та один раз до обласної дитячої лікарні з приводу гострих респіраторних захворювань з ознаками дихальної недостатності. За вказаний період дитина вже мала надлишкову масу тіла, індекс маси тіла - в межах 20,4-20,8 кг/м². Спостерігалось характерне розташування підшкірно-жирової клітковини (переважно на тулубі і проксимальних відділах кінцівок). Також відмічалась затримка в статокінетичному та мовленнєвого розвитку, мама відмічала лабільність настрою, істерику, у харчовій поведінці домінувало підвищення апетиту. Молекулярноцитогенетичне дослідження FISH-методом, каріотипування підтвердили мікроделіцію батьківської копії 15-ї хромосоми в локусі 15q11.2-q13, що дало можливість діагностувати вроджений синдром Прадера - Віллі [2, 11].

Результати та їх обговорення. Вроджені вади розвитку - структурні або функціональні, в тому числі і метаболічні, відхилення від норми, які формуються у

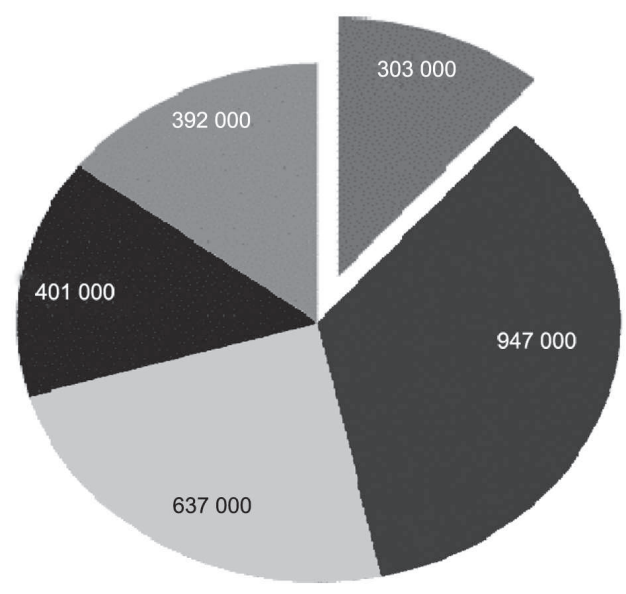

Структура малюкової смертності, за даними ВООЗ, впродовж 2000-2015pр. Також, за даними ВООЗ, у 2015 р. 2,68 млн дитячих смертей сталося у неонатальному періоді життя:

- вроджені анамалії; - передчасне народження; _ _ - асфіксія, травми при народженні; - неонатальний сепсис; - інші причини період внутрішньоутробного розвитку i можуть бути діагностовані як пренатально, так і на значно пізніших етапах життя [10]. За даними ВООЗ, у 2016 р. від вродженої патології впродовж перших 4 тиж життя померло понад чверть мільйона новонароджених. У 2015 р. в структурі неонатальної смертності вроджені вади у всьому світі поступалися лише недоношеності, асфіксії, пологовим травмам та неонатальному сепсису (рисунок) [12].

У половині випадків летальних вроджених вад не вдалося ідентифікувати безпосередню, конкретну причину порушення онтогенезу. Нині тригерними факторами порушення гісто- та органогенезу вважають соціально-економічні [14], генетичні $[13,16]$, інфекційні [15], екологічні чинники [6] та якісний і кількісний стан харчування матері $[9,10]$. Разом з тим аналіз даних дитячих аутопсій (середній вік дослідження дітей 18 міс), виконаний Medical Exaniners Office in the Arkansas Crime Laboratory, свідчить, що вроджені вади розвитку були виявлені у 13,2 \% (58) випад- 
ків, з них 17,2 \% (10) - секційні знахідки, які достовірно ( $>$ < 0,001) частіше виявляли у дітей старше 6 міс. Це вказує на достатньо високу якість пренатальних скринінгів та ефективність сучасних перинатальних технологій виходжування [17]. Отже, вроджені вади розвитку визнані важливою медико-соціальною, економічною, демографічною загрозою.

Слід зазначити, що Конгрес США ще в 1988 р. прийняв «Закон про запобігання вродженим вадам розвитку» (S419), який закликав до «... збирання, аналізу та опублікування даних про вроджені вади, ... забезпечення населення інформацією та освітніми матеріалами щодо запобігання цим аномаліям, ... створення Національної Інформаційної Палати з вроджених вад ...» [6]. Логічним продовженням боротьби із зростаючою вродженою патологією стала ініціатива ВООЗ “Global Strategy for Women’s, Children’s and Adolescents’ Health, 2016-2030”, що поставила за мету покращання стандартів охорони здоров'я і якості життя жінок і дітей шляхом імплементації зусиль міжнародних партнерів [12].

Вроджена патологія відображає порушення пренатального онтогенезу від моменту утворення зиготи до початку пологової діяльності. Відповідно до фаз внутрішньоутробного розвитку вирізняють гамето-, бласто-, ембріо- і фетопатії [8]. Гаметопатії - генні, хромосомні і геномні мутації безпосередньо у статевих клітинах батьків, які можуть бути причинами невиношування вагітності, вроджених вад розвитку. Близько 10 \% сперматозоїдів мають аномалії хромосом, 16 \% яйцеклітин не придатні до запліднення. Бластопатії - порушення бластогенезу в перші 15 діб після запліднення. Це надзвичайно чутливий період щодо пошкоджувальних факторів, внаслідок дії яких в переважній більшості випадків відбуваються загибель та елімінація зародка в терміні 5-7 тиж або формується летальна вроджена вада розвитку. Ембріопатії розвиваються у термін 8 тиж вагітності, асоціюються з множинними вадами, оскільки в цьому терміні відбуваються закладання і формування всіх систем і органів плода. Наступним критичним періодом внутрішньоутробного розвитку є термін від 9 до 28 тиж. Розрізняють ранню (до 28 тиж) та пізню (після 28 тиж) фетопатії. Зазвичай причинами вад розвитку у цьому терміні $є$ генералізована внутрішньоутробна інфекція з множинними вогнищами альтеруючого запалення в паренхіматозних органах, персистенцією екстрамедулярних вогнищ кровотворення, геморагічного синдрому, ознаками морфофункціональної незрілості та недоношеності, низької маси тіла при народженні $[1,8,10]$.

За етіологією розрізняють три групи вад розвитку: спадкові (гамето-, бластопатії) - мутація спадкового матеріалу у гаметах або зиготах на генному чи хромосомному рівні; екзогенні (ембріо- і фетопатії) - виникають внаслідок тератогенної дії на ембріон чи плід будь-яких екзо- та ендогенних чинників, зокрема діабетична фетопатія і алкогольний фетальний синдром. Мультифакторіальна етіологія вад розвитку зумовлена сумацією негативних наслідків мутацій спадкового матеріалу та впливу екзогенних чинників.

Також розрізняють вади первинні і вторинні - індуковані первинними змінами в гамето- та ембріогенезі. Ізольованими називають вади розвитку в межах однієї системи, множинні вади - поліорганне, полісистемне ураження. Загалом диференціація вроджених вад розвитку грунтується на анатомо-фізіологічному принципі будови людського організму [1].

Пацієнти з множинними вродженими вадами розвитку є актуальною та важливою медико-соціальною проблемою в сучасній парадигмі охорони здоров'я, оскільки перебіг інтеркурентних захворювань завжди обтяжений анатомофізіологічними та імунореактивними особливостями макроорганізму, що впливає на тактику лікарського супроводу і підбір схем ефективного лікування.

Значущі детермінанти постнатального онтогенезу дітей з підозрою на вроджену ваду розвитку:

- стигматизація;

- патерни ехоКГ, ЕКГ, систоло-діастолічні серцеві шуми виявлені під час аускультації серця;

- патерни НСГ - гідроцефалія, гіпоплазія, агенезія мозолистого тіла, агірія;

- втрата набутих навичок у психомоторному розвитку, його затримка; 
- гіпорефлексія, м'язова гіпотонія;

- повторні затяжні запальні захворювання (пневмонія, муковісцидоз, секвестрація легенів, ДМПП, ДМШП, судинні мальформації);

- затяжна жовтяниця (як маркер внутрішньоутробної інфекції та дисплазії сполучної тканини);

- порушення фізичного розвитку (надлишкова маса тіла або виснаження);

- $\quad$ гіпогонадизм;

- ознаки поліорганної недостатності;

- епізоди інфекції сечовидільної системи у грудному віці.

Алгоритм обстеження пацієнта з імовірною вродженою патологією повинен включати:

- загальноклінічне обов'язкове обстеження з встановленням нутрітивного статусу, оцінкою фізичного та психоморного розвитку;

- ультразвукове дослідження серця, органів черевної порожнини, головного мозку;

- визначення рівня адренокортикотропного (АКТГ), тиреотропного (ТТГ), соматотропного (СТГ) гормонів сироватки крові;

- визначення каріотипу, цитогенетичне дослідження;

- MPT і/або рентгенографія;

- медико-генетичне консультування.

Висновки. На підставі аналізу даних літератури та клінічного випадку запропоновано алгоритм верифікації вродженої патології сімейним лікарем, що включає визначення значущих клінічних симптомів та деяких патернів при додатковому лабораторно-інструментальному дослідженні і медико-генетичному консультуванні. Перспектива подальших досліджень полягає у пошуку і вивченні кореляційних зв'язків між встановленими клінічними детермінантами, ступенем тяжкості захворювання та віддаленими наслідками.

\section{С пи сокл л т ера ту ри}

1. Болезни плода, новорождённого и ребёнка. Нозология, диагностика, патологическая анатомия / Под ред. Е. Д. Черствого, Г. И. Кравцова. -Минск,1991. - С. 9-20.

2. Булак Г. В., Філик О.В. Складний клінічний випадок вродженого синдрому в ранньому дитячому віці // Практ. медицина: наук.практ. журн. - 2009. - Т. 15, № 1. - С. 6-9.

3. Булат Л. М., Лисунещь О. В., Дідик Н. В., Шінкарук-Диковицька М. М. Інтерактивні технології навчання та формування клінічного мислення у студентів молодших курсів медичного вишу // Вісн. Вінниц. нац. ун-ту. - 2014. - № 1, Т. 18, Ч. 2. C. $222-225$.

4. Булат Л. М., Меркулова Д. О., Лисунеиь О. В., Дідик Н. В. Якість навчання як важлива складова компетентністної освіти // Підготовка медичних кадрів у сучасних умовах реформи системи охорони здоров'я України. Тези доп. наук.-метод. конф. (Вінниця, 15 лют. 2017 р.). - Вінниця, 2017. - С. 19-20.

5. Васкес Абанто А. Э., Арельяно Васкес С. Б., Васкес Абанто X. Э. Интегративная медицина - залог успеха в XXI веке // Гуманітарний та інноваційний ракурс професійної майстерності: пошуки молодих учених. I міжнар. наук.-практ. конф.
1. Bolezni ploda, novorozhdyonnogo i rebyonka. Nozologiya, diagnostika, patologicheskaya anatomiya / Pod red. E. D. CHerstvogo, G. I. Kravcova. - Minsk,1991. - S. 9-20.

2. Bulak G. V., Filik O. V. Skladnij klinichnij vipadok vrodzhenogo sindromu v rann'omu dityachomu vici // Prakt. medicina: nauk.prakt. zhurn. - 2009. - T. 15, № 1. - S. 6-9.

3. Bulat L. M., Lisunec' O. V., Didik N.V., SHinkaruk-Dikovic'ka M. M. Interaktivni tekhnologiï navchannya ta formuvannya klinichnogo mislennya u studentiv molodshih kursiv medichnogo vishu // Visn. Vinnic. nac. un-tu. - 2014. - № 1, T. 18, Ch. 2. - S. 222-225.

4. Bulat L. M., Merkulova D. O., Lisunec' O. V., Didik $N$. $V$. YAkist' navchannya yak vazhliva skladova kompetentnistnoï osviti // Pidgotovka medichnih kadriv u suchasnih umovah reformi sistemi ohoroni zdorov'ya Ukraïni. Tezi dop. navch.-metod. kon. (Vinnicya, 15 lyut. 2017 r.). - Vinnicya, 2017. - S. 19-20.

5. Vaskes Abanto A. Eh., Arel'yano Vaskes S. B., Vaskes Abanto H. Eh. Integrativnaya medicina - zalog uspekha v HKHI veke // Gumanitarnij ta innovacijnij rakurs profesijnoï majsternosti: poshuki molodih uchenih. I mizhnar. nauk.-prakt. konf. 
студентів, аспірантів та молодих учених (Одеса, 24 квіт.). - С. 33-34.

6. Вертелещький В. Вроджені вади розвитку і Україна. - http://www.ibis-birthdefects. org/start/ukrainian/kievtxt.htm.

7. Дольницький О. В., Галан В. О., Ромадіна О. В. Природжені вади розвитку. Основи діагностики та лікування: монографія. - К., 2009. - С. 200-220.

8. Неонатологія / За ред. П. С. Мощича, О. Г. Суліми. - К., 2004. - С. 17-48.

9. Педіатрія: нац. підручник / За ред. В. В. Бережного. - К., 2013. - С. 10-45.

10. Пороки развития. Информационный бюллетень №370 Апрель 2015 http://www. who.int/mediacentre/factsheets/fs370/en/.

11. Хіменко Т. М., Адаховська А. О. Синдром Прадера - Віллі в практиці лікаря-педіатра, сучасні підходи у діагностиці та лікуванні // Здоров'я дитини. - 2015. Вип. 64, № 4. - С. 118-123.

12. Congenital anomalies Fact sheet Updated September 2016. - http://www.who.int/mediacentre/factsheets/fs370/en/.

13. Down Syndrome: Genetics, Screening and Health / Edited by Jelinek, D; Dvorak, G // Handbook of Down Syndrome Reseach. - 2009. - P. 1-54.

14. Nso A. P., Garcia-Bermejo C., Larru B. et al. Pathology in children of HIV women // Indian J. of Pediatrics. - 2009. - Vol. 76 (Issua 11). - P. 1125-1130.

15. Shah Ankit, Kumar Anil Zika. Virus Infection and Development of a Murine Model // Neurotoxicity Reseach. - 2016. - Vol. 30 (Issua 2). - P. 131-134.

16. Tunaoglu F. Sedef, Yildirim Ayse, Vurali Dogus Isolated. Congenital Heart Block / Texas Heart Institute J. - 2010. - Vol. 37 (Issua 5). - P. 579-583.

17. Parham D. M., Savell V. H., Kokes C. P. et al. Incidence of autopsy findings in unexpected deaths of children and adolescents / Conference: Interim Meeting of the Society - for-Pediatric-Pathology Location: Vancouver, Canada, Sep, 2000.

\section{ДИАГНОСТИКА ВРОЖДЁННОЙ ПАТОЛОГИИ В ПРАКТИКЕ СЕМЕЙНОГО ВРАЧА}

\section{О. В. Лисунеи, Н. В. Дидък (Винница)}

В статье приведены принципы классификации врождённых пороков развития. Описан клинический случай синдрома Прадера - Вилли в раннем детском возрасте. Предложен алгоритм диагностического поиска, способствуещего верификации диагноза семейным врачом. Выделены важнейшие клинические детерминанты диагностики врождённой патологии - стигмы дизэмбриогенеза, нарушения физического и психомоторного развития, гипогонадизм, затяжная желтуха в период новорождённости, специфические паттерны при инструментальных исследованиях.

Ключевые слова: врождённая патология, семейный доктор, диагностика, дети, синдром Прадера - Вилли.

\section{DIAGNOSTICS OF CONGENITAL PATHOLOGY IN FAMILY PHYSICIAN'S PRACTICE}

O. V. Lysunets, N. V. Didyk (Vinnytsya, Ukraine)

\section{National Pirogov Memorial Medical University Vinnytsya}

The article includes the principles of classification of congenital pathology. The clinical case of congenital syndrom of Pradera - Villi in the pre-preschool period of the life is descrabting. The important clinical determinants that can be used for diagnostic search of family physician have been determined. The most important the clinical determinants of congenital pathology are the stigmatas, physical growth violations, delaying of neurophychological growth, frequent and prolonget episodes of inflammatory diseases, longer jaundice in the neonatal period of life, hypogonadysm, patterns of instrumental investigations.

Key words: congenital pathology, a family physician, diagnostics, children, syndrom Pradera - Villi. 